\title{
Errata
}

\section{Erratum: Sepers et al., "Endocannabinoid-Specific Impairment in Synaptic Plasticity in Striatum of Huntington's Disease Mouse Model"}

In the article "Endocannabinoid-Specific Impairment in Synaptic Plasticity in Striatum of Huntington's Disease Mouse Model" by Marja D. Sepers, Amy Smith-Dijak, Jeff LeDue, Karolina Kolodziejczyk, Ken Mackie, and Lynn A. Raymond, which appeared on pages 544-554 of the January 17, 2018 issue, the following information was omitted from the Acknowledgments: "We thank Dr. Amber Southwell and Dr. Michael Hayden, Centre for Molecular Medicine and Therapeutics, University of British Columbia, for providing the Q175FDN mice used in this study. Additional funding support for this study was provided by the Huntington Society of Canada." This error does not affect the conclusions of the paper. The article has been corrected online.

DOI: $10.1523 / J N E U R O S C I .0375-19.2019$

\section{Erratum: "This Week in the Journal"}

In "This Week in the Journal", which appeared on page 577 of the January 23, 2019 issue, a sentence in NMDA Receptors in Amacrine Cells of the Rod Pathway appeared incorrectly. In the last paragraph, the third sentence should instead read: "Activation of GluN2Acontaining NMDARs in A17 amacrines, in contrast, likely inhibits further glutamate release from rod bipolar cells." The article has been corrected online.

DOI: 10.1523/JNEUROSCI.0376-19.2019 